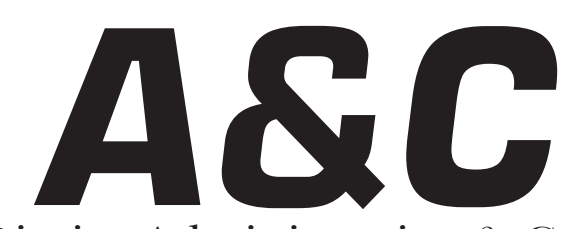

Revista de Direito Administrativo \& Constitucional

Editora Fórum

ISSN 1516-3210

\begin{tabular}{|l|l|l|l|l|l|}
\hline A\&C R. de Dir. Administrativo \& Constitucional & Belo Horizonte & ano 7 & n. 30 & p. 1-254 & out./dez. 2007 \\
\hline
\end{tabular}




\section{A\&C REVISTA DE DIREITO ADMINISTRATIVO \& CONSTITUCIONAL}

IPDA

Instituto Paranaense

de Direito Administrativo

Direção Geral

Romeu Felipe Bacellar Filho

Direção Editorial

Paulo Roberto Ferreira Motta

Direção Executiva

Emerson Gabardo

Conselho de Redação

Edgar Chiuratto Guimarães

Adriana da Costa Ricardo Schier

Célio Heitor Guimarães

\section{Conselho Editorial}

Jorge Luís Salomoni - in memoriam (Argentina)

José Carlos Abraão (Brasil)

José Eduardo Martins Cardoso (Brasil)

José Luís Said (Argentina)

José Mario Serrate Paz (Uruguai)

Juan Pablo Cajarville Peruffo (Uruguai)

Juarez Freitas (Brasil)

Julio Rodolfo Comadira - in memoriam (Argentina)

Luís Enrique Chase Plate (Paraguai)

Lúcia Valle Figueiredo (Brasil)

Manoel de Oliveira Franco Sobrinho -

in memoriam (Brasil)

in memoriam (Brasil)

Marçal Justen Filho (Brasil)

Marcelo Figueiredo (Brasil)
Márcio Cammarosano (Brasil)
Maria Cristina Cesar de Oliveira (Brasil)

Nelson Figueiredo (Brasil)

Odilon Borges Junior (Brasil)

Pascual Caiella (Argentina)

Paulo Eduardo Garrido Modesto (Brasil)

Paulo Henrique Blasi (Brasil)

Paulo Neves de Carvalho - in memoriam

(Brasil)

Paulo Ricardo Schier (Brasil)

Pedro Paulo de Almeida Dutra (Brasil)

Regina Maria Macedo Nery Ferrari (Brasil)

Rogério Gesta Leal (Brasil)

Rolando Pantoja Bauzá (Chile)

Sérgio Ferraz (Brasil)

Valmir Pontes Filho (Brasil)

Yara Stropa (Brasil)

Weida Zancaner (Brasil)

A246 A\&C Revista de Direito Administrativo \& Constitucional. ano 3, n. 11, jan./mar. 2003. Belo Horizonte: Fórum, 2003.

Trimestral

ano 1, n. 1, 1999 até ano 2, n.10, 2002 publicada pela

Editora Juruá em Curitiba

ISSN 1516-3210

1. Direito Administrativo. 2. Direito Constitucional.

I. Fórum.

CDD: 342 CDU: 33.342

(C) Editora Fórum Ltda. 2007

Todos os direitos reservados. É proibida a reprodução total ou parcial, de qualquer forma ou por qualquer meio eletrônico ou mecânico, inclusive através de processos xerográficos, de fotocópias ou de gravação, sem permissão por escrito do possuidor dos direitos de cópias (Lei n 9.610, de 19.02.1998).

Editora Fórum Ltda

Av. Afonso Pena, 2770 - 15\%16 andar - Funcionários

CEP 30130-007 - Belo Horizonte/MG - Brasil

Tel.: 08007043737

Internet: www.editoraforum.com.br

e-mail: editoraforum@editoraforum.com.br
Editor responsável: Luís Cláudio Rodrigues Ferreira Coordenação editorial: Olga M. A. Sousa

Pesquisa jurídica: Fátima Ribeiro - OAB/MG 74868

Revisora: Bárbara Christiane

Projeto gráfico: Luis Alberto Pimenta

Diagramação: Marcelo Belico

Bibliotecária: Alessandra Rodrigues da Silva -

CRB 2459 - 6 ${ }^{a}$ região

Os conceitos e opiniões expressas nos trabalhos assinados são de responsabilidade exclusiva de seus autores.

Impressa no Brasil / Printed in Brazil

Distribuída em todo o Território Nacional 


\title{
Notas sobre publicidade e transparência na Lei de Responsabilidade Fiscal no Bra- sil
}

\author{
Fabrício Motta \\ Doutor em Direito do Estado (USP). Presidente do Instituto de Direito Administrativo de Goiás \\ (IDAG). Procurador do Ministério Público junto ao TCM-GO.
}

Palavras-chave: Lei de Responsabilidade Fiscal. Princípio da publicidade. Princípio da transparência. Princípio da legalidade.

Sumário: Introdução - 1 Os princípios da publicidade e transparência administrativas - 2 O princípio da transparência fiscal - 3 Publicidade e transparência na Lei de Responsabilidade Fiscal - 3.1 Publicidade e o Relatório de Gestão Fiscal - 4 Notas finais - Referências

\section{Introdução}

O presente estudo dedica-se à breve análise dos princípios da publicidade e transparência, insculpidos na Lei Complementar $n^{\circ}$ 101/00, conhecida amplamente como Lei de Responsabilidade Fiscal. Toma-se como pressuposto inicial a afirmação de que a Administração Pública é diretamente afetada pela ótica constitucionalista: a idéia de submissão à legalidade, ponto nodal do Direito Administrativo, sofre considerável mudança de enfoque, deixando de se falar em "submissão à lei estrita" para falar-se em "submissão ao Direito", composto, sobretudo, de princípios e regras como componentes do gênero "normas". O controle da Administração passa, então, a exigir vinculação das atividades e atos à lei e ao direito, em uma concepção flexível e axiológica da legalidade, tendo como balizas os princípios que configuram o Estado Brasileiro. ${ }^{1}$

\section{Os princípios da publicidade e transparência administrativas}

Na esteira dos ensinamentos doutrinários mais autorizados, ${ }^{2}$ podemos

\footnotetext{
${ }^{1}$ De acordo com Odete Medauar, "o princípio da legalidade também em outros ordenamentos passou a assentar-se em bases valorativas, 'amarrando' a Administração não somente à lei votada pelo Legislativo, mas também aos preceitos fundamentais que norteiam todo o ordenamento. Assim, por este aspecto, o princípio da legalidade significa não mais a relação lei-ato administrativo, mas a dimensão global, ordenamento-Administração" (MEDAUAR, 2003, p. 147).

${ }^{2}$ A esse respeito: MEDAUAR, Odete. O direito administrativo em evolução. 2. ed. rev. atual e ampl. São Paulo: Revista dos Tribunais, 2003 e BAPTISTA, Patrícia. Transformações do Direito Administrativo, Rio de Janeiro: Renovar, 2003.
} 
asseverar que, na linha de transformação de Direito Administrativo, a Administração Pública distancia-se da rigidez autoritária e aproxima-se da flexibilidade democrática, ${ }^{3}$ por intermédio principalmente da absorção de valores e princípios constitucionais e da assimilação de uma nova temática de relacionamento entre Estado e sociedade. ${ }^{4}$ Como componente indispensável deste cenário, o princípio democrático, visto por alguns como direito fundamental de quarta geração, exsurge como “o mais excelso princípio de nosso ordenamento, condicionante tanto das regras políticas como jurídicas da Lei Maior", segundo Paulo Bonavides. ${ }^{5}$ A constitucionalização dos princípios e regras tocantes à Administração Pública, como decorrência lógica do triunfo do constitucionalismo, somada à necessária importância do princípio democrático, permite que se imagine a publicidade como um dos meios de legitimação da Administração, pressuposto necessário à efetivação da participação popular.

O princípio da publicidade administrativa caracteriza-se também como direito fundamental do cidadão, indissociável do princípio democrático, possuindo um substrato positivo - o dever estatal de promover amplo e livre acesso à informação como condição necessária ao conhecimento, à participação e ao controle da Administração - e outro negativo — salvo no que afete à segurança da sociedade e do Estado e o direito à intimidade, as ações administrativas não podem desenvolver-se em segredo. ${ }^{6}$

Este direito fundamental parece efetivar-se em quatro vertentes:

a) direito de conhecer todos os expedientes e motivos referentes à ação administrativa, bem como seus desdobramentos e resultados, em razão do direito fundamental à informação;

b) garantia frente ao processo de produção de decisões administrativas, em contraposição ao segredo procedimental, por meio da audiência dos envolvidos e interessados, em razão do princípio da ampla defesa;

c) direito subjetivo de acesso aos arquivos e registros públicos, em decorrência direta do princípio democrático;

\footnotetext{
${ }^{3}$ Expressões do jurista João Batista Gomes Moreira.

${ }^{4}$ MEDAUAR, 2003, p. 267.

${ }^{5}$ BONAVIDES, 2001, p. 127

${ }^{6}$ CANOTILHO, 2003.
}

A\&C R. de Dir. Administrativo \& Constitucional, Belo Horizonte, ano 7, n. 30, p. 91-108, out./dez. 2007 
d) direito de exigir do Estado ações positivas para possibilitar a visibilidade, cognoscibilidade, e controle das ações administrativas. ${ }^{7}$

A Constituição Brasileira conferiu, ao princípio da publicidade, tratamento privilegiado. Com efeito, podem ser destacados os seguintes direitos fundamentais colocados no catálogo do art. $5^{\circ}$ e ligados, direta ou indiretamente, à concretização de tal princípio:

Art. $5^{\circ}-[\ldots]$

XXXIII - todos têm direito a receber dos órgãos públicos informações de seu interesse particular, ou de interesse coletivo ou geral, que serão prestadas no prazo da lei, sob pena de responsabilidade, ressalvadas aquelas cujo sigilo seja imprescindível à segurança da sociedade e do Estado;

XXXIV - são a todos assegurados, independentemente do pagamento de taxas: a) o direito de petição aos Poderes Públicos em defesa de direitos ou contra ilegalidade ou abuso de poder;

b) a obtenção de certidões em repartições públicas para defesa de direitos e esclarecimento de situações de interesse pessoal;

$[\ldots]$

LXXII - conceder-se-á habeas-data:

a) para assegurar o conhecimento de informaçóes relativas à pessoa do impetrante, constantes de registros ou bancos de dados de entidades governamentais ou de caráter público;

b) para a retificação de dados, quando não se prefira fazê-lo por processo sigiloso, judicial ou administrativo;

$[\ldots]$

LX - a lei só poderá restringir a publicidade dos atos processuais quando a defesa da intimidade ou o interesse social o exigirem.

Ainda na análise dos dispositivos constitucionais, é importante relembrar que as decisões administrativas dos tribunais devem ser obrigatoriamente motivadas e em sessão pública, sob pena de inconstitucionalidade por afronta ao artigo 94 , inciso $\mathrm{X}$.

O princípio da publicidade das questões administrativas é tema central nos regimes democráticos contemporâneos. A publicidade constitui, como referido, um princípio ínsito à democracia, ${ }^{8}$ que somente pode ser mitiga-

7 BOBBIO, 1989, p. 89. Em recente decisão, o Tribunal de Contas de União recomendou ao Gabinete Civil da Presidência da República "que, em obediência ao princípio da publicidade expresso no art.37 da Constituição Federal e no precedente do Supremo Tribunal Federal ao julgar o MS 24.725 MC/DF, tome as providências necessárias à divulgação dos dados e informações constantes dos sistemas Siafi, Sidor, Siasg, Spiu e Siape, necessárias à transparência dos gastos públicos e ao controle social, resguardados os dados indispensáveis à segurança da sociedade e do Estado e à preservação da privacidade dos dados individuais dos servidores públicos" (Acórdão 1526/2005-Plenário; DOU, 07 out. 2005).

A\&C R. de Dir. Administrativo \& Constitucional, Belo Horizonte, ano 7, n. 30, p. 91-108, out./dez. 2007 
do em situações excepcionais e com fundadas razões. Segundo Cármen Lúcia Antunes Rocha, “[...] a publicidade da Administração é que confere certeza às condutas estatais e segurança aos direitos individuais e políticos dos cidadãos. Sem ela, a ambigüidade diante das práticas administrativas conduz à insegurança jurídica e à ruptura do elemento de confiança que o cidadão tem que depositar no Estado". ${ }^{9}$

É importante, ao considerar a Administração como necessariamente aberta e permeável ao público, fazer referência ao pensamento de Kant, que considera como "fórmula transcendental do direito público" o princípio segundo o qual "todas as ações relativas ao direito de outros homens cuja máxima não é conciliável com a publicidade são injustas". ${ }^{10}$ Nesse mesmo sentido, lembrando-se que o Direito Administrativo surgiu como reação ao absolutismo, a visibilidade da atuação administrativa é, mais que tendência, necessidade no atual estágio do constitucionalismo e das relações Estado-sociedade. Assim, entende-se que a publicidade é requisito essencial para a eficácia do controle do poder, além de elemento indissociável da noção de Estado de Direito.

Nessa linha de raciocínio, por trás do princípio da publicidade, estão a exigência de segurança do direito e a proibição da política do "segredo", entendida esta última proibição não somente como uma vedação ao arbítrio, mas como um dever de informar por parte do Estado. ${ }^{11} \mathrm{O}$ princípio da publicidade, em suma, protege o cidadão de intromissões indevidas da Administração em sua esfera de liberdade constitucionalmente protegida. Em recente e importante decisão, ensinou o Ministro do Supremo Tribunal Federal Celso de Mello:

Os postulados constitucionais da publicidade, da moralidade e da responsabilida-

\footnotetext{
${ }^{8}$ Cumpre transcrever, sobre democracia representativa e representatividade, passagem lapidar de Carl Schmitt, citado por Bobbio: "a representação apenas pode ocorrer na esfera da publicidade. Não existe nenhuma representação que se desenvolva em segredo ou a portas fechadas. Um parlamento tem um caráter representativo apenas enquanto se acredita que sua atividade própria seja pública. Sessões secretas, acordos e decisões secretas de qualquer comitê podem ser muito significativos e importantes, mas não podem jamais ter um caráter representativo" (BOBBIO, 1989, p. 101).

${ }^{9}$ ROCHA, 1994, p. 240.

${ }^{10}$ Apud BOBBIO, 1989, p. 104.

${ }^{11}$ CANOTILHO, 2003, p. 1165. Na correta lição de Juarez Freitas (2004, p. 56): "[...] o agente público precisa prestar contas de todos os seus atos e velar para que tudo seja feito com a visibilidade do sol do meio-dia, preservando sua própria reputação, somente se admitindo que não o faça por excepcional e estrita exigência superior do interesse público (v.g., de segurança) ou por ditames da dignidade da pessoa humana. Filosoficamente, o normal é que tudo que não possa vir a público deva ser encarado como suspeito de incorreção, nada havendo que não deva ser, de algum jeito ou em certo tempo, revelado nos regimes democráticos".
} 
de - indissociáveis da diretriz que consagra a prática republicana do poder — não permitem que temas, como os da destinação, da utilização e da comprovação dos gastos pertinentes a recursos públicos, sejam postos sob inconcebível regime de sigilo. Não custa rememorar que os estatutos do poder, numa República fundada em bases democráticas, não podem privilegiar o mistério, eis que a legitimidade político-jurídica da ordem democrática, impregnada de necessário substrato ético, somente é compatível com um regime do poder visível, definido, na lição de Bobbio, como "um modelo ideal do governo público em público". - Ao dessacralizar o segredo, a nova Constituição do Brasil restaurou o velho dogma republicano e expôs o Estado, em plenitude, ao princípio democrático da publicidade, cuja incidência - sobre repudiar qualquer compromisso com o mistério - atua como fator de legitimação das decisões e dos atos governamentais. - O novo estatuto político brasileiro - que rejeita o poder que oculta e que não tolera o poder que se oculta — consagrou a publicidade dos atos e das atividades estatais como expressivo valor constitucional, incluindo-o, tal a magnitude desse postulado, no rol dos direitos, das garantias e das liberdades fundamentais. ${ }^{12}$

Destaque-se que a visibilidade necessariamente conferida à Administração possibilita o combate à ineficácia das disposições de garantia legalmente instituídas. Em obra sobre a chamada "Administração paralela", identificada como aquela que se constitui de procedimentos informais paralelos aos formalmente estabelecidos, Agustín Gordillo ${ }^{13}$ ensina com maestria que

[...] mesmo com as leis e constituições consagrando enfaticamente o princípio da publicidade dos atos do governo e também o mais irrestrito acesso dos interessados às atuações administrativas, salvo se forem qualificadas por ato expresso e motivado como confidenciais, a verdade é que, na prática, estas disposições jamais são cumpridas facilmente. A tradição das administrações hispanoamericanas é o silêncio, o segredo, a reserva, não a publicidade. $\mathrm{O}$ funcionário público não considera, com isso, que realiza uma atividade ilícita: ao contrário, percebe que o correto, o devido, o lícito e normal é ser o zeloso guardião de toda a informação administrativa e, sobretudo, não possibilitar o acesso a ela dos administrados ou terceiros, pois isso poderia comprometê-lo. Se o funcionário for informado da lei que dispõe em sentido contrário, sua incredulidade será genuína: ele imaginará que essa norma é ilegal, sem saber como nem por que, mas terá consciência de que a conduta que se espera dele, por parte da sociedade, não é em absoluto aquela descrita na lei, mas sim aquela que é apreendida, sem nenhuma dificuldade, de seus superiores e companheiros de trabalho.

\footnotetext{
${ }^{12}$ Decisão proferida, liminarmente, no MS 24.725, ainda pendente de publicação, divulgada no Informativo $n^{\circ} 331$ do Supremo Tribunal Federal. Disponível em: <http://www.stf.gov.br/informativo>. Acesso em: 10 out. 2005. 13 GORDWO, 1992, p. 54, tradução nossa.

${ }^{14}$ Anota Odete Medauar (2003, p. 235): "O secreto, invisível, reinante na Administração, mostra-se contrário ao
} 
O autor conclui que a participação popular e a publicidade na elaboração das normas tocantes à Administração são condições de sua futura eficácia, evitando a criação de um parassistema, ou, segundo a terminologia de Bobbio, de um poder invisível. Estas idéias trazem consigo a noção de transparência administrativa. ${ }^{14}$

Wallace Paiva Martins Júnior entende que o princípio da transparência administrativa é composto pelos subprincípios da publicidade, da motivação e da participação popular na gestão administrativa. Relacionando o princípio da transparência com a idéia de Estado Democrático de Direito, o autor anota:

Em escala decrescente, o princípio da transparência é inerência do princípio democrático (princípio fundamental estruturante) e, à míngua de clara e precisa denominação normativo-constitucional, resulta como o valor impresso e o fim expresso pelos princípios da publicidade, da motivação e da participação popular, uma vez que todos apontam para a visibilidade da atuação administrativa e inspiram a produção de regras como o direito de petição, e certidão, e o direito à informação, tidos como mecanismos essenciais no controle jurisdicional da transparência. ${ }^{15}$

Marcos Juruena Vilella Souto, por sua vez, esposa entendimento original ao buscar para o princípio da transparência um significado diverso do comumente atribuído ao princípio da publicidade:

Ao que parece, por transparência se quer muito mais, lançando-se, aqui, a idéia de que o verdadeiro controle visível ou transparente se dá quando se revela a intimidade das autoridades investidas de poder, naquilo que se refere ao exercício desse poder. Em outras palavras, o exercício de uma função pública, voltada para o público, deve permitir o seu constante acompanhamento, sem que o direito de intimidade, inegável aos indivíduos, especialmente contra o próprio Estado, possa ser alegado para afastar esses controles. ${ }^{16}$

As idéias de publicidade e transparência parecem ser complementares. A partir da acepção comum das palavras, pode-se entender a

caráter democrático do Estado. A publicidade ampla contribui para garantir direitos dos administrados; em nível mais geral, assegura condições de legalidade objetiva porque atribui à população o direito de conhecer o modo como a Administração atua e toma decisões; "abate o muro secreto da cidadela administrativa", possibilitando o controle permanente sobre suas atividades (...) com a publicidade como regra, tem-se "o diálogo em lugar do mutismo, a transparência em lugar da opacidade", e suscita-se a confiança do administrado na Administração".

15 MARTINS JÚNIOR, 2004, p. 31.

${ }^{16}$ SOUTO, 2007, p. 37. Cabe transcrever a acertada conclusão do autor: "[...] a opção pelo exercício da autoridade, mormente em tempos em que a corrupção é um dos maiores males do país, exige que se renuncie à proteção da intimidade diante dos temas que podem interferir no exercício do poder, bem como que se apresente, de forma transparente, o interesse público que se deseja defender no exercício do cargo público".

17 MENDES, 2001, p. 334.

18 TORRES, 2000

${ }^{19}$ Informativo de Direito Administrativo e Responsabilidade Fiscal - IDAF, seção Doutrina/Parecer/Comentários, 
publicidade como característica do que é público, conhecido, não mantido secreto. Transparência, ao seu turno, é atributo do que é transparente, límpido, cristalino, visível; é o que se deixa perpassar pela luz e ver nitidamente o que está por trás. Os atos administrativos, impõe a conclusão, devem ser públicos e transparentes - públicos porque devem ser levados a conhecimento dos interessados por meio dos instrumentos legalmente previstos (citação, publicação, comunicação, etc.); transparentes porque devem permitir enxergar com clareza seu conteúdo e todos os elementos de sua composição, inclusive o motivo e a finalidade, para que seja possível efetivar seu controle.

\section{0 princípio da transparência fiscal}

Transpondo a análise feita para o campo do direito financeiro, tendo como necessário pano de fundo o sistema constitucional, pode-se afirmar sem ressalvas que, em razão dos princípios republicano e democrático, é possível identificar um princípio implícito da transparência fiscal em nosso sistema constitucional. Como bem explica Gilmar Ferreira Mendes, ${ }^{17}$

O princípio da transparência ou clareza foi estabelecido pela Constituição de 1988 como pedra de toque do Direito Financeiro. Poderia ser considerado mesmo um princípio constitucional vinculado à idéia de segurança orçamentária. Nesse sentido, a idéia de transparência possui a importante função de fornecer subsídios para o debate acerca das finanças públicas, o que permite uma maior fiscalização das contas públicas por parte dos órgãos competentes e, mais amplamente, da própria sociedade. A busca pela transparência é também a busca pela legitimidade.

No mesmo sentido a lição de Ricardo Lobo Torres, ${ }^{18}$ para quem a transparência fiscal é um princípio constitucional implícito, que sinaliza no sentido de que a atividade financeira deve se desenvolver segundo os ditames da clareza, abertura e simplicidade. Dirige-se, assim, ao Estado como à sociedade, tanto aos organismos financeiros supranacionais quanto às entidades não-governamentais, e baliza a problemática a elaboração do orçamento e sua gestão responsável.

O que se tem chamado de princípio da transparência fiscal é implicitamente extraído de diversas regras constitucionais, também contribuindo para sua identificação a centralização do processo de elaboração

\footnotetext{
edição n. 06, p. 524, jan. 2002

${ }^{20}$ OLIVEIRA 2002, p. 17.
}

A\&C R. de Dir. Administrativo \& Constitucional, Belo Horizonte, ano 7, n. 30, p. 91-108, out./dez. 2007 
orçamentária no Poder Legislativo. Merecem destaque, contudo, os parágrafos $1^{\circ}$ e $6^{\circ}$ do art.165, que determinam, respectivamente:

$\S 1^{\circ}$ - A lei que instituir o plano plurianual estabelecerá, de forma regionalizada, as diretrizes, objetivos e metas da administração pública federal para as despesas de capital e outras delas decorrentes e para as relativas aos programas de duração continuada.

$\S 6^{\circ}$ - O projeto de lei orçamentária será acompanhado de demonstrativo regionalizado do efeito, sobre as receitas e despesas, decorrente de isenções, anistias, remissões, subsídios e benefícios de natureza financeira, tributária e creditícia.

De acordo com a lição de Marcelo Figueiredo: ${ }^{19}$

Ao lado do planejamento responsável, a lei alude a transparência, também conceito novo, que vem dar maior elasticidade ao princípio da publicidade, garantia constitucional. Do modo em que inserida na lei, a transparência surge não somente como imperativo, como também com o objetivo de informar a decisão do Administrador. (...)

O princípio da transparência concretiza o princípio da cidadania (artigo $1^{\circ}$, inciso I da CF) e oferece meios para que os cidadãos brasileiros possam, não somente compreender a gestão dos recursos públicos, como efetivamente participar desse processo administrativo. Não se conceberia que a transparência pudesse apenas ser uma obrigação formal da administração, um requisito a ser cumprido para dar eficácia à boa gestão fiscal. É mais do que isso. Acreditamos que seja ademais de um requisito legal, uma necessidade para dar legitimidade às decisões do administrador, fundamentando suas opções técnicas e políticas em matéria de planejamento fiscal. De nada valeria todo o esforço de incentivo à participação se não pudesse a população e as entidades interessadas efetivamente opinar e, sobretudo, influenciar a decisão administrativa. A "apreciação" exige conhecimento, explicação minuciosa das peças orçamentárias, preparação de quem vai examinar e esclarecimento de quem exibe a conta, enfim, transparência e participação para efetivar a cidadania. Nesse sentido, o mandatário divide a responsabilidade com a sociedade. Decide segundo as possibilidades, com o respaldo de pressões legítimas.

Tais regras, nitidamente inspiradas pelos princípios republicano e democrático, objetivam permitir o controle das leis orçamentárias, de forma a verificar se possibilitam, ainda que indiretamente, amparar o poder público na consecução dos objetivos da República. Não obstantes, estas normas devem assegurar transparência de informações e clareza de linguagem, de forma a possibilitar, para o cidadão e também para os entes públicos, o correto entendimento das leis orçamentárias. A falta de trans-

${ }^{21}$ MILESKI, 2002, p. 27

22 Disponível em: <www.planejamento.gov.br>.

A\&C R. de Dir. Administrativo \& Constitucional, Belo Horizonte, ano 7, n. 30, p. 91-108, out./dez. 2007 
parência e de sinceridade orçamentárias pode comprometer não somente o regime republicano democrático como também o sistema federalista, por não permitir o adequado planejamento por parte dos entes públicos.

\section{Publicidade e transparência na Lei de Responsabilidade Fiscal}

A Lei Complementar $n^{\circ} 101$, de 4 de maio de 2000, estabelece normas de finanças públicas voltadas para a responsabilidade na gestão fiscal, com amparo no Capítulo II do Título VI da Constituição Federal. Os princípios que embasam a chamada Lei de Responsabilidade Fiscal advém do próprio texto constitucional, como a moralidade, a publicidade, a economicidade, dentre outros. A lei em comento alcança os Poderes Executivo, Legislativo, inclusive Tribunais de Contas, Judiciário e o Ministério Público, bem como os respectivos órgãos da administração direta, os fundos, autarquias, fundações e empresas estatais dependentes. O novo diploma, atendendo ao anseio social de cobrança de responsabilidade no trato com os recursos públicos, segundo Régis Fernandes de Oliveira

[...] veio sanar espaço punitivo contra o mau administrador público. Estabelece ela requisitos imprescindíveis no âmbito financeiro público, para cumprimento pelos administradores. O político que gerencia o ente estatal como se fosse coisa sua passará a ter problemas sérios. O desequilíbrio orçamentário, o gasto excessivo com pessoal, as operações irresponsáveis de crédito, o descuido com o patrimônio público, tudo passa a ser fiscalizado e sancionado pela lei nova. ${ }^{20}$

A transparência certamente constitui um dos mais importantes pilares de apoio e sustentação da Lei de Responsabilidade Fiscal. Exigência imposta por inspiração republicana e democrática,

[...] a transparência fiscal se revela como um mecanismo democrático que busca o fortalecimento da cidadania, servindo de pressuposto ao controle social e forma de valorar e tornar mais eficiente o sistema de controle das contas públicas, na medida em que enfatiza a obrigatoriedade de informação ao cidadão sobre a estrutura e funções de governo, os fins da política fiscal adotada, qual a orientação para elaboração e execução dos planos de governo, a situação das contas públicas e as respectivas prestações de contas. ${ }^{21}$

O Manual de Boas Práticas para a Gestão Fiscal, ${ }^{22}$ proposto e divulgado pelo Fundo Monetário Internacional e uma das fontes inspiradoras

23 OLIVEIRA, 2002, p. 96.

24 BANDEIRA DE MELLO, 1999, p. 317.

${ }^{25}$ A Lei orgânica do TCU — Lei no 8.443/92 —, por exemplo, estabelece em seu art.30: "Ao Tribunal de Contas da 
da Lei de Responsabilidade Fiscal, elege quatro princípios gerais como sustentáculo da transparência fiscal: a) Princípio da definição clara de funções e responsabilidades; b) Princípio do acesso público geral à informação; c) Princípio da abertura na preparação, execução e prestação de contas do orçamento; e d) Princípio da garantia de integridade das informações fiscais. Pode-se dizer, sem qualquer temor, que direta ou indiretamente todos estes princípios foram acolhidos por nosso ordenamento.

Em virtude dos objetivos do presente estudo, deixamos de tecer comentários de maior relevância acerca de aspectos gerais da LRF, remetendo o leitor para as obras específicas, algumas de indiscutível qualidade, a respeito do assunto. Ao tratar, logo em seu artigo inicial, dos pressupostos da chamada "gestão fiscal responsável”, entendeu o legislador que é necessária "ação planejada e transparente, em que se previnem riscos e corrigem desvios capazes de afetar o equilíbrio das contas públicas, mediante o cumprimento de metas de resultados entre receitas e despesas e a obediência a limites e condições no que tange a renúncia de receita, geração de despesas com pessoal, da seguridade social e outras, dívidas consolidada e mobiliária, operações de crédito, inclusive por antecipação de receita, concessão de garantia e inscrição em Restos a Pagar" (destacamos; art. $1^{\circ}, \S 1^{\circ}$ da Lei de Responsabilidade Fiscal). Uma breve análise é capaz de demonstrar que a preocupação com a publicidade e transparência perpassam todo o conteúdo da Lei de Responsabilidade Fiscal. Nesse sentido, é relevante destacar:

a) a importância da participação popular, assegurada sobretudo mediante incentivo à participação popular e realização de audiências públicas, durante os processos de elaboração e de discussão dos planos, lei de diretrizes orçamentárias e orçamentos (art.48, parágrafo único). A respeito das audiências públicas entende Régis Fernandes de Oliveira: constituírem "condição obrigatória como requisito de validade de aprovação dos textos orçamentários. Superada a fase do orçamento autoritário, resolvido dentro de quatro paredes, por autoridades e especialistas na área. Sem audiência do povo, inadmissível a aprovação do orçamento, que pode ser questionado em Juízo. Assim, a audiência popular é requisito de validade para a vigência do orçamento";23

União, no âmbito de sua competência e jurisdição, assiste o poder regulamentar, podendo, em conseqüência,

A\&C R. de Dir. Administrativo \& Constitucional, Belo Horizonte, ano 7, n. 30, p. 91-108, out./dez. 2007 
b) $\mathrm{O}$ estabelecimento de instrumentos de transparência da gestão fiscal, aos quais será dada ampla divulgação, inclusive em meios eletrônicos de acesso público a saber: os planos, orçamentos e leis de diretrizes orçamentárias; as prestações de contas e o respectivo parecer prévio; o Relatório Resumido da Execução Orçamentária e o Relatório de Gestão Fiscal; e as versões simplificadas desses documentos;

c) O dever de publicação do Relatório de Gestão Fiscal $\left(\operatorname{art} .55, \S^{\circ}\right.$ ) e do Relatório Resumido de Execução Orçamentária (art.52)

d) A ampla divulgação que deverá ser dada aos resultados da apreciação das contas, julgadas ou tomadas (art.56, §3º); e

e) A criação de um "Conselho de Gestão Fiscal" para acompanhamento e avaliação, de forma permanente, da política e da operacionalidade da gestão fiscal constituído por representantes de todos os Poderes e esferas de Governo, do Ministério Público e de entidades técnicas representativas da sociedade (art.67).

\subsection{Publicidade e o Relatório de Gestão Fiscal}

Previsto no Capítulo IX da Lei comentada, intitulado "Da transparência, controle e fiscalização", o Relatório de Gestão Fiscal é a pedra de toque da LRF, instrumento determinante para os quatro pontos principais da lei: planejamento, transparência, controle e responsabilização. Determina o artigo 54 da Lei Complementar $n^{\circ}$ 101/00:

Art.54. Ao final de cada quadrimestre será emitido pelos titulares dos Poderes e órgãos referidos no art.20 Relatório de Gestão Fiscal, assinado pelo:

I - Chefe do Poder Executivo;

Art.55.

(...)

$\S 2^{\circ} \mathrm{O}$ relatório será publicado até trinta dias após o encerramento do período a que corresponder, com amplo acesso ao público, inclusive por meio eletrônico.

Reconhecendo a importância da publicidade — inerente ao regime democrático - e da fiscalização para o alcance da responsabilidade na gestão fiscal, estatui a Lei n ${ }^{0} 10.028 / 00$ sanção para condutas que atentem contra tais determinações:

A\&C R. de Dir. Administrativo \& Constitucional, Belo Horizonte, ano 7, n. 30, p. 91-108, out./dez. 2007 
Art. $5^{\circ}$ Constitui infração administrativa contra as leis de finanças públicas:

I - deixar de divulgar ou de enviar ao Poder Legislativo e ao Tribunal de Contas o relatório de gestão fiscal, nos prazos e condições estabelecidos em lei;

$\S 1^{\circ}$ A infração prevista neste artigo é punida com multa de trinta por cento dos vencimentos anuais do agente que lhe der causa, sendo o pagamento da multa de sua responsabilidade pessoal.

$\S 2^{\circ} \mathrm{A}$ infração a que se refere este artigo será processada e julgada pelo Tribunal de Contas a que competir a fiscalização contábil, financeira e orçamentária da pessoa jurídica de direito público envolvida.

O dispositivo citado merece interpretação atenta. Inicialmente, a utilização da conjunção "ou” permite concluir que são tipificadas como infrações, de forma alternativa, ambas as condutas. É imperioso ressaltar que tanto a ausência de divulgação quanto a desídia no encaminhamento ao Tribunal de Contas do Relatório de Gestão Fiscal são puníveis com a multa prevista no parágrafo primeiro. Não se exige, neste caso, a cumulatividade das condutas.

Desta maneira, deve-se primeiramente encarecer que tão somente a falta de encaminhamento do Relatório ao Tribunal de Contas competente já sujeita o Administrador à multa no valor equivalente a $30 \%$ de seus vencimentos anuais. Por outro lado, o prazo para encaminhamento do referido Relatório à Corte de Contas deve ser disciplinado pela própria Corte, no exercício de sua função normativa. Entende-se, neste particular, que a expressão "lei" constante do artigo $5^{\circ}$, inciso I da Lei ${ }^{\circ}$ 10.028/00 deve ser interpretada em seu sentido amplo.

A respeito do poder regulamentar, ensina Celso Antônio Bandeira de Mello; ${ }^{24}$

A Constituição prevê os regulamentos executivos porque o cumprimento de determinadas leis pressupõe uma interferência de órgãos administrativos para a aplicação do que nelas se dispõe, sem, entretanto, predeterminar exaustivamente, isto é, com todas as minúcias, a forma exata da atuação administrativa pressuposta (...) ditas normas são requeridas para que se disponha sobre o modo de agir dos órgãos administrativos, tanto no que concerne aos aspectos procedimentais de seu comportamento quanto no que respeita aos critérios que devem obedecer em questões de fundo, como condição para cumprir os objetivos da lei.

Não se registram divergências pontuais quanto ao poder normativo atribuído pelo ordenamento jurídico aos Tribunais de Contas. Com efeito, as Constituições Estaduais e as Leis Orgânicas da cada Tribunal costumam atribuir competências genéricas para o exercício do controle externo, não 


\section{descendo a minúcias. ${ }^{25}$ Como ensina Luciano Ferraz, ${ }^{26}$}

Contudo, hipóteses há em que as leis orgânicas não estabelecem minuciosamente todos os detalhes para que a obrigação pública de prestar contas seja adimplida pelo responsável (v.g., prazo, forma, modo, rotinas). Quando isso acontece, tem cabimento a edição de um ato normativo subseqüente. Assim, os regimentos internos e instruções normativas dos Tribunais de Contas são atos que cumprem o desiderato de estabelecer as situações concretas que dão lugar à obrigação pública de prestar contas.

Em algumas situações, o ordenamento admite o exercício implícito da função normativa. A existência de competências implícitas é creditada, sobretudo, à força normativa da Constituição e à vinculação direta da Administração aos seus preceitos, acenando, inclusive, para a possibilidade de aplicação direta da mesma, sem intermediação legislativa, em algumas hipóteses. Não se deve considerar tais competências como um privilégio da Administração, pois estão necessária e estritamente ligadas ao alcance de objetivos constitucionais, possuindo natureza instrumental. Para evitar que a adoção da técnica das competências implícitas signifique adesão à máxima maquiavélica de que os fins justificam os meios, é também sumamente importante assegurar seu exercício rigidamente subordinado aos princípios e valores constitucionais. ${ }^{27}$ Também não custa ressaltar que tais competências devem profundo respeito aos princípios da reserva legal e da preeminência da lei. ${ }^{28}$

Pode-se afirmar que o estabelecimento dos meios necessários para o cumprimento das competências constitucionais ou legais deve ser feito, em atenção aos princípios da isonomia, segurança jurídica e publicidade, por ato normativo. A

Ihe devam ser submetidos, obrigando ao seu cumprimento, sob pena de responsabilidade".

${ }^{26}$ FERRAZ, 2002.

${ }^{27}$ Bonavides (2006, p. 433) expõe a natureza da técnica e suas preocupações: "É, ao mesmo tempo, a técnica que, partidos os laços de origem, e consequentemente emancipada de toda a servidão ideológica, pode, com a máxima eficácia, se constituir num instrumento interpretativo de toda Constituição, não importa o conteúdo material nem as premissas teóricas fundamentais sobre as quais repouse. Vale assim de princípio deveras idôneo com que conduzir indiferentemente a construção jurídica do modelo constitucional sem relação necessária com este ou aquele quadro de princípios e valores, perante os quais pode de todo neutralizar-se. Em rigor, como instrumento aplicável, é mais uma técnica do que um princípio - princípio e técnica fora conjuntamente no constitucionalismo americano do século XIX".

${ }^{28}$ A respeito da distinção entre reserva de lei e preeminência ou preferência da lei, leciona Alberto Xavier (1979, p. 331): "[...] temos um princípio de reserva da lei apenas naquela matéria que se traduz na criação de deveres e obrigações. Porque em tudo aquilo que está fora do campo, bem definido, da criação de deveres e obrigações, o princípio da legalidade valerá apenas como preeminência da lei, mas não necessariamente como reserva da lei".

${ }^{29}$ FERRAZ, Ibid.

30 Informativo de Licitaçôes e Contratos, Zênite, p. 10-120, fev. 2004.

${ }^{31}$ Destacamos. Acórdão n 317/2003-Plenário; DOU , 11 abr. 2003. Na ocasião, considerando a reincidência do órgão no descumprimento dos prazos legais e a omissão do gestor (ex-Presidente do TRE/AP), foi fixada multa 
conclusão forçosa é que a disciplina para o encaminhamento do Relatório de Gestão Fiscal a esta Corte deve ser disciplinada por ato normativo do próprio Tribunal de Contas competente. Nessa linha de raciocínio,

As hipóteses em que a regulamentação, por intermédio de atos normativos, têm lugar se apresentam quando o texto da lei se mostra insuficiente, incompleto, sendo necessário: a) desdobrar seu conteúdo sintético; b) limitar a discricionariedade administrativa definindo regras procedimentais para a Administração ou caracterizando fatos, situações ou comportamentos enunciados na lei, mediante conceitos legais vagos, os quais, para a exata definição, envolvam critérios técnicos ('normas administrativas em branco').

Serão estas as hipóteses em que o Tribunal de Contas poderá exercer competência normativa, destacando-se como a mais importante, a possibilidade de definir regras procedimentais. É onde se enquadram os atos que obrigam os administradores submetidos ao controle dos Tribunais de Contas a enviar periodicamente relatórios, comprovantes, documentos, segundo critérios e prazos determinados. O descumprimento dessas determinações poderá dar ensejo à aplicação de penalidades. ${ }^{29}$

Obviamente, a função normativa encontra limites estabelecidos em lei e nas normas constitucionais. No presente caso, não pode ser estabelecido prazo desarrazoado, em desacordo com os prazos de elaboração previstos na Lei de Responsabilidade Fiscal. O prazo estabelecido por ato normativo deve ser divulgado com a antecedência necessária ao seu conhecimento e cumprimento pelos gestores públicos.

É importante também interpretar de forma correta os vocábulos divulgar e publicar, que se fazem presentes no diploma antes comentado. A respeito de publicidade e divulgação, escreveu Diogenes Gasparini: ${ }^{30}$

A publicidade legal, não porque haja publicidade ilegal, mas porque exigida pela lei, é a notícia oficial de atos, contratos e demais instrumentos jurídicos da responsabilidade da Administração Pública, para conhecimento, início dos efeitos, desencadeamento de prazos recursais e prescricionais e controle. Sua razão é a necessidade de ser a Administração Pública transparente em todas suas atuações. (...)

A publicação legal para sua plena realização é a do jornal oficial de divulgação ou imprensa oficial, não sendo assim considerada a simples notícia veiculada pela mídia, mesmo que ocorra em programa radiofônico ou televisivo destinado a noticiar os atos oficiais da Administração Pública, conforme já decidiu o STF ao julgar o RE 71.652 (RDA 111:145). Imprensa oficial é o jornal público especialmente instituído por lei para a divulgação dos atos, contratos e outros instrumentos legais e jurídicos da Administração Pública. É chamado de diário

no valor de $\mathrm{R} \$ 10.000,00$ (dez mil reais).

${ }^{32}$ Segundo a conhecida construção de Norberto Bobbio, "democracia é o governo do poder público em público".

A\&C R. de Dir. Administrativo \& Constitucional, Belo Horizonte, ano 7, n. 30, p. 91-108, out./dez. 2007 
oficial (DOU, DOE, DOM). Não se confunde com o órgão ou entidade criado para sua edição, como é o caso da imprensa nacional.

A par dessa modalidade de publicação oficial, outra é instituída e viabilizada por afixação do instrumento jurídico a ser noticiado em quadro de editais, colocado em local de fácil acesso na sede da Administração Pública cuja publicação lhe cabe, a exemplo do que ocorre com a publicação da carta-convite. A lei instituidora do diário oficial deve indicar qual a publicidade oficial exeqüível mediante afixação, não ficando, desse modo, a escolha da modalidade à discrição da Administração Pública que deve satisfazer a exigência da publicação. Se nada dispuser, pela simples existência da imprensa oficial, há de se entender vedada a publicação por afixação. A regra é a publicidade dos atos, contratos e outros instrumentos jurídicos da responsabilidade da Administração Pública no diário oficial e por inteiro, embora a lei possa autorizar sua notícia resumida, como ocorre com os editais licitatórios e com os contratos e aditamentos por ela celebrados.

Analisando caso concreto envolvendo a publicação dos Anexos da Lei de Diretrizes Orçamentárias, e enfrentando a existência ou não de diferença entre "publicar" e "divulgar" entendeu o Tribunal de Contas do Estado de São Paulo:

Na sistemática da Lei de Responsabilidade Fiscal, há distinção. Bem analisados, de um lado, os dispositivos que utilizam o verbo publicar (ou derivações dele) e, de outro lado, os que aludem a divulgar (ou variantes), percebe-se a diferença. Divulgar significa dar amplo conhecimento por qualquer meio; publicar significa dar amplo conhecimento pela imprensa. Confira-se, por exemplo, que quando a Lei se refere à transparência obtida pela utilização de meios eletrônicos (Internet) se refere a divulgar, nunca a publicar. Nesse sentido, a exigência de publicação do Relatório Resumido da Execução Orçamentária na imprensa oficial alcança todo tipo de Município, pequeno, médio ou grande (...) Portanto, a afixação, na sede da Prefeitura, do Relatório Resumido da Execução Orçamentária e seus demonstrativos não supre a obrigação de sua publicação na imprensa. (Destaques originais. TC 1075/008/01; Rel. Cons. Cláudio Ferraz de Alvarenga)

Apesar da divergência semântica entre os termos, não pode o hermeneuta procurar solução que vulnere contundentemente a razão de existir do art. $5^{\circ}$ da Lei Federal $n^{\circ}$ 10.028/00, a saber: o de punir, entre outras, a conduta do agente público que, sem demonstrar a existência de justa causa, encaminhar tardiamente o Relatório de Gestão Fiscal ao órgão de controle externo. O preceito cominatório da multa, não bastasse sua redação taxativa, é de ordem pública. Assim sendo, embora não afaste a possibilidade de purgação da mora, não autoriza a remissão pura e simples da sanção pecuniária ali veiculada. Ainda mais quando ausente

A\&C R. de Dir. Administrativo \& Constitucional, Belo Horizonte, ano 7, n. 30, p. 91-108, out./dez. 2007 
justificativa robusta para o descumprimento da obrigação imposta em lei.

Desta maneira, como existe a obrigação legal de publicar o Relatório de Gestão Fiscal até trinta dias após o encerramento do período a que corresponder, com amplo acesso ao público, inclusive por meio eletrônico. (art.54, $\S 2^{\circ}$ da Lei de Responsabilidade Fiscal), parece não haver justificativa para se entender o termo divulgar, como utilizado na Lei $\mathrm{n}^{\circ}$ 10.028/00, como tocante apenas às formas de publicidade que não sejam no veículo oficial do ente. A melhor solução, para o objetivo pedagógico e ao mesmo tempo sancionador pregado pela legislação, parece ser a compreensão do verbo "divulgar" em sentido amplo, abrangendo, nesta situação, o termo "publicar". Sintetizando a questão, a sanção deve alcançar também o gestor que não publicar na imprensa oficial o Relatório de Gestão Fiscal dentro do prazo determinado.

É importante destacar que o Tribunal de Contas da União entendeu possível a gradação da multa referida, mesmo diante da taxatividade da Lei $\mathrm{n}^{\mathrm{o}}$ 10.028/00. Como ressaltou o relator, Ministro Walton Alencar Rodrigues,

Como toda sanção de natureza punitiva, a medida da punição decorre do juízo de valor a ser feito sobre a gravidade da conduta e dos limites máximos e mínimos definidos em lei. Para evitar injustiças, considero que a multa prevista no artigo $5^{\circ}, \S 1^{\circ}$ da Lei 10.028/2000 deve ser aquilatada pelo juiz e entendida como de até $30 \%$ dos vencimentos anuais do gestor, conferindo ao aplicador da norma a necessária margem de valoração da conduta para fixação do seu valor. ${ }^{31}$

\section{Notas finais}

Para a efetivação do princípio democrático na Administração Pública, ${ }^{32}$ que nesta se materializa por meio da participação e do controle sociais, é imprescindível o direito à informação do desenvolvimento das atividades administrativas. É condição insuficiente, mas necessária, que a Administração atue, em regra, publicamente. Entende-se por público, aqui, o que é manifesto, aberto ao conhecimento geral, feito diante de espectadores, e privado o que se diz ou se faz num círculo restrito e, no limite, em segredo.

O princípio da publicidade administrativa, insculpido no art.37 da Constituição da República e disseminado, indiretamente, por todo o texto ${ }^{33}$ BOBBIO, 1989. 
constitucional, é decorrência direta dos princípios republicano e democrático consagrados no artigo $1^{\circ}$ da mesma Carta. Nesse sentido, conceitualmente, o problema do caráter público do poder sempre serviu para diferenciar a democracia, caracterizada pelo controle público do poder e na idade moderna pela livre formação de um opinião pública, e o principado, cujo método de governo contempla inclusive o recurso aos arcana imperii, isto é, ao segredo de Estado que num Estado de Direito moderno é previsto apenas como remédio excepcional. ${ }^{33}$

A Lei de Responsabilidade Fiscal apresenta-se como mais um importante diploma legislativo que, na tendência de afastar a Administração do autoritarismo e aproximá-la do cidadão, impõe uma série de regras sobre finanças públicas. A transparência no manejo dos recursos públicos, por meio de uma série de instrumentos estabelecidos para proporcionar ao cidadão plena visibilidade da movimentação administrativa, constitui-se em um dos mais importantes pilares de sustentação da nova lei. Incumbe ao aplicador do direito, na sua missão de assegurar a maior eficácia possível à Constituição Republicana, cercar-se de cautelas para direcionar sua interpretação sempre no sentido da maior publicidade e transparência possíveis. Ao cidadão, fonte e destino de toda forma de poder, cabe fazer bom e pleno uso dessa transparência para bem fiscalizar a persecução dos objetivos da República.

\section{Referências}

BANDEIRA DE MELLO, Celso Antônio. Conteúdo jurídico do princípio da igualdade. 3. ed. São Paulo: Malheiros, 2002.

BANDEIRA DE MELLO, Celso Antônio. Curso de direito administrativo. 11.ed. São Paulo: Malheiros, 1999.

BARROSO, Luís Roberto. Fundamentos teóricos e filosóficos do novo direito constitucional brasileiro. Revista de Direito Administrativo, São Paulo; v. 225, p. 5-37, jul./set.2001.

BOBBIO, Norberto. O futuro da democracia. Tradução: Marco Aurélio Nogueira. Rio de Janeiro: Paz e Terra, 1989.

BONAVIDES, Paulo. Teoria constitucional da democracia participativa. São Paulo: Malheiros, 2001.

CANOtilho, J. J. Gomes. Direito constitucional e Teoria da Constituição. 7.ed. Coimbra: Almedina, 2003.

A\&C R. de Dir. Administrativo \& Constitucional, Belo Horizonte, ano 7, n. 30, p. 91-108, out./dez. 2007 
FERRAZ, Luciano. Poder de coerção e poder de sanção dos Tribunais de Contas - Competência normativa e devido processo legal. Revista Fórum Administrativo, Belo Horizonte, v. 14, p.437-440, abr. 2002.

FREITAS, Juarez. O controle dos atos administrativos e os princípios fundamentais. 3. ed. atual e ampl. São Paulo: Malheiros, 2004.

GORDILLO, Agustín. La administración paralela. Madrid: Civitas, 1992.

MARTINS JÚNIOR, Wallace Paiva. Transparência administrativa: publicidade, motivação e participação popular. São Paulo: Saraiva, 2004.

MARTINS, Ives Gandra da Silva; NASCIMENTO, Carlos Valder do. Comentários à Lei de Responsabilidade Fiscal (Org.). São Paulo: Saraiva, 2001.

MEDAUAR, Odete. A processualidade no direito administrativo. São Paulo: R. dos Tribunais, 1993.

MEDAUAR, Odete. $O$ direito administrativo em evolução. 2.ed. rev, atual e ampl. São Paulo: R. dos Tribunais, 2003.

MOREIRA, João Batista Gomes. Direito administrativo: da rigidez autoritária à flexibilidade democrática. Belo Horizonte: Fórum, 2005.

OLIVEIRA, Régis Fernandes de. Responsabilidade fiscal. 2. ed. rev. São Paulo: R. dos Tribunais, 2002.

ROCHA, Cármen Lúcia Antunes. Princípios constitucionais do processo administrativo no direito brasileiro. Revista Trimestral de Direito Público, n. 17, p. 5-33, 1997.

ROCHA, Cármen Lúcia Antunes. Princípios constitucionais dos servidores públicos. São Paulo: Saraiva, 1999.

SOUTO, Marcos Juruena Vilela. Transparência na Administração Pública. Revista do TCM-RJ, Rio de Janeiro, n. 35, p.37-38, maio 2007.

TORRES, Ricardo Lobo. Tratado de direito constitucional financeiro e tributário, volume V: o orçamento na Constituição. 2. ed. rev. e atual. Rio de Janeiro: Renovar, 2000.

XAVIER, Alberto. Legalidade e tributação. Revista de Direito Público, São Paulo, n.47-48, p.329-335, jul./dez. 1978.

Informação bibliográfica deste texto, conforme a NBR 6023:2002 da Associação Brasileira de Normas Técnicas (ABNT):

MOTTA, Fabrício. Notas sobre publicidade e transparência na Lei de Responsabilidade Fiscal no Brasil. A\&C Revista de Direito Administrativo \& Constitucional, Belo Horizonte, ano 7, n. 30, p. 91-108, out./dez. 2007. 